\begin{tabular}{|l|l|l|l|}
\hline Eiszeitalter u. Gegenwart & 35 & $1-4$ & Hannover 1985 \\
\hline
\end{tabular}

\title{
Field Conference 1984 of the INQUA Subcommission on Shorelines of Northwestern Europe
}

\author{
HANSJÖRG STREIF ${ }^{*}$ )
}

Field conference, excursion, INQUA, paleogeography, morphogenetical processes, shorelines, geological traverse, sedimentary sequences, classification, Weichselian Late Glacial, estuaries. Northwest German Plains (Jade Bay region, Weser estuary, Elbe estuary),

Niedersachsen, Schleswig-Holstein, Jutland, Skagen, Klim, North Sea, Baltic Sea

A b s t r a c t : The conference included an excursion along a geological traverse which extended from the Jade Bay region, the Weser estuary and lower Elbe, along the west coast of Schleswig-Holstein and Denmark as far as Skagen. It dealt with paleogeographical changes of the coast lines, sedimentary sequences, and the stratigraphical classification of the Weichselian Late Glacial and Holocene morphogenetical processes. A symposium at Klim, Denmark, was dedicated to comparable phenomena in the entire North Sea and Baltic Sea areas.

[Feldkonferenz 1984 der INQUA Subkommission für Küstenlinien von Nordwesteuropa]

$\mathrm{Ku} \mathrm{r} \mathrm{z} \mathrm{f} \mathrm{a} \mathrm{s} \mathrm{s} \mathrm{u} \mathrm{n} \mathrm{g:} \mathrm{Die} \mathrm{Veranstaltung} \mathrm{umfaßte} \mathrm{eine} \mathrm{Exkursion} \mathrm{entlang} \mathrm{einer} \mathrm{geolo-}$ gischen Traverse vom Wesermündungs- und Jadebusengebiet über den Unterelberaum, die schleswig-holsteinische und dänische Westküste bis Skagen. Dabei wurden die paläogeographischen Veränderungen der Küstenlinien, die Sedimentabfolgen und zeitliche Einstufung der morphogenetischen Prozesse des Weichsel-Spätglazials und Holozän untersucht. Ein Symposium in Klim, Dänemark, befaßte sich mit gleichen Themen aus dem gesamten Nord- und Ostseebereich.

The 1984 field conference of the INQUA Subcommission on Shorelines of Northwestern Europe was held between September 15 and 21 and was attended by twentysix scientists from eleven countries. The conference included an excursion from Bremen to Alborg, and a symposium was held on September 20 at Klim, Denmark.

The basic concept of the field conference was to study a traverse along the southeastern North Sea coast from the zone of relative subsidence in Jade Bay and the Weser and Elbe estuaries to the zone of isostatic uplift in the northern part of Jutland. Stratigraphically the conference dealt with the Quaternary evolution of the North Sea

*) Address of the autor: Dr. H. StreIF, Niedersächsisches Landesamt für Bodenforschung, Stilleweg 2, D - 3000 Hannover 51. 
basin, especially the marine transgressions of the Holsteinian interglacial period (Elster to Saale interglacial), the Eemian interglacial period (Saale to Weichsel interglacial), and the late Weichselian to Holocene development.

The pattern and gradient of the fluvial low terrace formed in the Weichselian period was demonstrated along the 1 o w e $r$ W e s e $r$. This terrace is overlain by a system of river dunes formed in the late Weichselian to early Holocene periods. During the middle and young Holocene both units were covered by peat, lagoonal, and river bank deposits, indicating a rising water level and semiterrestrial to freshwater environments. Only the uppermost layer of the Holocene sequence is a tidal flat sediment of the marine facies zone.

The Holocene sequence of the $\mathrm{J}$ a d e B a y $\mathrm{reg}$ i o $\mathrm{n}$ is characterized by repeated transgressive and regressive overlaps which synchronously affected a wide coastal area. Additionally, the phenomenon of „Klappklei” formation was demonstrated in the Sehestedter Außendeichsmoor. During storm surges, this bog is split horizontally and its upper part floats on a wedge of sea water. When the water falls to its normal height, a thin layer of formerly suspended material is left behind in the fissure in the peat sequence.

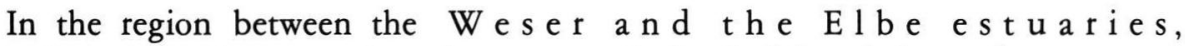
the landscape development since the younger Saale glacial period was demonstrated in the Bederkesa area. This includes the Eemian marine ingression, periglacial processes of the Weichsel Pleniglacial and the late Weichselian to Holocene formation of lakes and bogs which was repeatedly interrupted by short periods of marine incursions. In the Arensch area near Cuxhaven, sedimentological and paleoecological finds were shown to support the hypothesis of atmospheric influences, e. g. storms and changes in air pressure, on shoreline displacement and coastal sedimentation in the Holocene.

The reaction of man to the encroaching sea was studied in two areas. In the marshes of Land Wursten, settling began on the flat surface in the Roman Iron Age. Under the influence of flooding from the 1st Century A. D. onward, the „Wurten”, which are artificially raised dwelling mounds, were built. This phase ended in the middle of the 5th Century A. D. Renewed habitation began about the 8 th Century on pre-existing Wurten, but also on natural elevations in the marshes. This was followed by a second period of raising dwelling mounds, and from $1000 \mathrm{~A}$. D. onward the construction of dike systems prevailed. In the Pleistocene hinterland of Land Hadeln, large scale archeological excavations provide an opportunity to trace settlements and their economic background back to Neolithic times.

The coastal Holocene of Dith mars che $\mathrm{n}$ a $\mathrm{nd} \mathrm{Eiderstedt}$ in $\mathrm{Schleswig-Holstein} \mathrm{is} \mathrm{characterized} \mathrm{by} \mathrm{barrier} \mathrm{systems.} \mathrm{In} \mathrm{the} \mathrm{Dith-}$ marschen area, the coastal zone is bounded to the east by cliffs in Pleistocene deposits. These cliffs were formed by meltwater streams of the Saale and Weichsel glacial periods, but have been partly rejuvenated by the Holocene sea producing a graded shoreline with a general north-south direction consisting of cliffs and beach barrier systems. These systems occur as single, narrow and elongated barriers, but also as fanlike spit systems, called „Donns". 
On the Eiderstedt peninsula there are three fan-shaped, east-west and northwest-southeast oriented barrier systems. The present-day plant communities and pollen assemblages on the barriers of St. Peter-Böhl offer a key for the reconstruction of paleo water levels for the Holocene barrier systems according to the principle of uniformitarianism.

In the coastal zone of $\mathrm{N}$ or $\mathrm{th} \mathrm{Fr}$ i e s 1 a $\mathrm{nd}$, the excursion dealt with the Holocene sedimentary sequence and the formation of the small marsh islands called the „Halligen". Additionally, the processes of colonization and the remnants of agriculture and peat cutting for salt production left behind by the storm surges of 1362 and 1634 were studied. These finds can be observed in the subsoil of the present-day Halligen and in abrasion zones of the adjacent tidal flats.

The region of the $\mathrm{Ringk} \phi \mathrm{bing}$ and $\mathrm{Nis}$ i u $\mathrm{Fjords}$ in $\mathrm{D}$ e $\mathrm{n} \mathrm{m} \mathrm{a} \mathrm{r} \mathrm{k,} \mathrm{offered} \mathrm{an} \mathrm{example} \mathrm{of} \mathrm{human} \mathrm{impact} \mathrm{on} \mathrm{natural} \mathrm{sedimentation} \mathrm{and}$ erosion processes along barrier systems. The history of the different technical measures, their original purposes and their actual results were explained. This was made with reference to the dredging of permanent outlets of lagoons to the sea, the construction of harbours, jetties and groins, as well as beach nourishment.

The landscape development of the $\mathrm{L}$ i $\mathrm{m} \mathrm{f} \mathrm{j}$ or $\mathrm{d}$ a $\mathrm{r}$ e a since the Saale glacial period is characterized by a marine Eeminan transgression, ice pushing during the Weichselian glaciation, and a very steep rise in sea level in the Boreal, and oscillations of the water level in the Atlantic and Subboreal periods. Human habitation of the area can be traced back to the kitchen middens of the Erteb $\phi$ lle culture. Historical sources indicate the existence of former natural outlets from the Limfjord to the North Sea, but their locations, as well as their dating, is still doubtful. From the description of the fauna in the Limfjord, conclusions can be drawn about its salinity from the 17th Century onwards.

$\mathrm{V}$ e n d s y s s e l, the northernmost part of Jutland, offered the possibility of studying the stratigraphy and facies of the middle to late Weichselian marine deposits of the Yoldia Sea and the marine Holocene sediments of the Littorina Sea. Both sedimentary units form expansive plains of different elevations which contrast destinctly from the hilly morphology of the glacial highlands built up by glaciofluvial and moraine deposits. The highest shoreline is now at about $56-62 \mathrm{~m}$ above sea level at Frederikshaven, descending to the southwest to $13 \mathrm{~m}$ at Gjöl, due to isostatic rebound.

A comprehensive and well documented guide book was published for the excursion with contributions from the following institutions: Niedersächsisches Landesamt für Bodenforschung, Niedersächsisches Landesinstitut für Marschen- und Wurtenforschung, Geologisches Landesamt Hamburg, Geologisches Landesamt Schleswig-Holstein, Institut für Ur- und Frühgeschichte der Universität Kiel, Geological Survey of Denmark, Geologisk Institut and Laboratoriet for palaeontolgi og stratigrafi Aarhus Universitet, and Geological Museum Copenhagen.

A symposium at Klim was dedicated to the evolution of the North Sea and the Baltic Sea during the Quaternary and dealt with 4 main topics: 
- Morphological, geological, and paleontological studies in the North Sea region on the basis of micro and macrofaunas and pollen analysis (offshore zone of the Southern North Sea, Jutland (Denmark), North Frisia (Germany), Western Coastal Plain (Belgium), and Brittany (France).

- Comparison of sea-level chronologies and correlation of transgressive and regressive cycles of the Holocene (England, The Netherlands).

- Evidence for and influence of storm surge events on the Holocene sedimentation (Eastern Scotland, northwestern Germany).

The reports given at this symposium and a few papers which are closely related to its topics are published in this volume of Eiszeitalter und Gegenwart. These papers include two different kinds of contributions: Progress reports for some fields of research are presented in the form of extended summaries. They contrast with the more detailed original contributions.

\section{References}

InquA (1984): Field Conference 1984, September 15-21, North Sea coastal zone between Jade Bay and Jammer Bight. - 104 pp.; Hannover.

Manuscript accepted on 21.3.1984 